\title{
Upaya Meningkatkan Daya Serap Belajar Siswa Pada Kompetensi Memahami Ketentuan Hukum Bacaan Mad ‘Iwad Melalui Metode Diskusi Di Kelas VIII-B MTs NW Karang Baru
}

\author{
Musabbihin \\ ucaks91@gmail.com \\ Madrasah Tsanawiyah NW Karang Baru, Lombok Timur, NTB, Indonesia.
}

\begin{abstract}
Abstrak
Proses pembelajaran Al qur'an Hadits guru dituntut untuk lebih kreatif dalam menggunakan metode, model dan strategi pembelajaran, sehingga akan diikuti dengan peningkatan daya serap belajar siswa. Penelitian ini bertujuan untuk mengetahui apakah dengan penerapan Metode diskusi dapat meningkatkan daya serap belajar siswa Kelas VIII B MTs NW Karang Baru Tahun Pelajaran 2021-2022 pada Mata Pelajaran Al-Qur'an Hadist Pada Kompetensi Memahami Ketentuan Hukum Bacaan Mad 'Iwad. Subyek penelitian ini adalah siswa kelas VIII B MTs NW Karang Baru Tahun Pelajaran 2021-2022 dengan jumlah 22 siswa perempuan. Berdasarkan data dari hasil post test pada siklus I, terdapat siswa yang mencapai ketuntasan terdapat 17 siswa dengan persentase $77,3 \%$, sedangkan siswa hasil belajarnya belum tuntas mencapai 5 siswa dengan persentase $22,7 \%$, sedangkan hasil pretes siswa, terdapat siswa yang mencapai ketuntasan terdapat 10 siswa dengan persentase $44,45 \%$, sedangkan siswa yang tidak tuntas mencapai 12 siswa dengan persentase $54,54 \%$, dengan demikian, penerapan diskusi pada siklus I daya serap belajar siswa terdapat peningkatan dari sebelum pelaksanaan, yaitu: siswa yang mencapai ketuntasan pada hasil pretes mencapai $44,45 \%$, dan ketuntasan pada hasil postest siklus I mencapai $77,2 \%$ terhadap peningkatan 32,85\%, sedangkan siswa yang belum mencapai ketuntasan menurun $31,84 \%$. Pada siklus II daya serap belajar siswa terdapat peningkatan sebelum pelaksanaan, yaitu siswa mencapai ketuntasan dari hasil pretest mencapai $77,7 \%$, dan ketuntasan dari hasil post test siklus II mencapai 95,45\% terdapat peningkatan 18,15\%, sedangkan siswa ya belum mencapai ketuntasan pada hasil pre test $22,7 \%$, dan siswa yang belum mencapai ketuntasan pada hasil post test siklus II mencapai 4,54 \% terdapat siswa yang belum mencapai ketuntasan menurun sebesar $18,16 \%$. Berdasarkan hasil penelitian di atas, maka dapat disimpulkan bahwa penerapan metode diskusi dapat meningkatkan daya serap siswa untuk belajar bersama dan meningkatkan hasil belajar.
\end{abstract}

Kata kunci : Daya Serap, Diskusi.

\section{Pendahuluan}

Tugas pendidikan adalah menciptakan suasana pembelajaran yang dapat membuat siswa untuk senantiasa belajar dengan baik dan bersemangat. Suasana pembelajaran yang demikian akan berdampak positif dalam pencapaian hasil belajar yang optimal. Guru sebaiknya memiliki kemampuan dalam memilih metode atau strategi pembelajaran yang tepat. Ketidaktepatan dalam penggunaan metode atau strategi pembelajaran akan menimbulkan kejenuhan bagi siswa dalam menerima materi 
yang disampaikan sehingga materi kurang dapat dipahami dan mengakibatkan siswa menjadi apatis yang nantinya akan berpengaruh terhadap daya serap belajar ${ }^{\text {. }}$

Daya serap adalah kemampuan atau kekuatan untuk melakukan sesuatu untuk bertindak dalam menyerap pelajaran. Daya serap berasal dari kata "daya" yang berarti kekuatan, kemampuan, dan "serap" yang berarti mengambil. Jadi daya serap dapat dikatakan sebagai suatu kemampuan untuk menangkap dan memahami sebuah materi hingga peserta didik dapat menjabarkan kembali materi yang diterima dengan benar. Dan daya serap menjadi tolak ukur untuk mengetahui sejauh mana pemahaman peserta didik terhadap mata pelajaran yang diajarkan oleh seorang guru dalam proses kegiatan belajar mengajar.

Metode adalah teknik penyajian yang dikuasai guru untuk mengajar atau menyajikan bahan pelajaran kepada siswa didalam kelas, baik secara individual atau kelompok/klasikal, agar pelajaran itu dapat diserap, dipahami dan dimanfaatkan oleh siswa dengan baik. ${ }^{2}$ Melalui metode pembelajaran ruang kelas menjadi hidup. Proses belajar mengajar tidak lagi berpusat kepada guru akan tetapi lebih kepada murid ${ }^{3}$. Adapun salah satu metode pembelajaran yang berpusat kepada siswa adalah metode diskusi. Metode ini sering digunakan pada tingkat MI/MTS/MA/Perguruan Tinggi dan lain-lain pada setiap mata pelajaran. Ini menjadi bukti bahwa metode ini lebih menarik perhatian peserta didik, karena semua yang ada di dalamnya akan ikut serta dalam pemecahan masalah sehingga ruangan menjadi hidup dan kondusif. Disamping itu, metode ini dapat melatih bagaimana cara bertanya dan menjawab yang baik, dan menghargai pendapat orang lain.

Sesuai studi pendahuluan yang penulis lakukan di MTs NW Karang Baru tentang proses belajar mengajar pada mata pelajaran Qur'an Hadits materi tentang ketentuan hukum bacaan mad 'iwad terdapat beberapa masalah sebagai berikut: (1) Kurangnya kemampuan siswa dalam menyelesaikan tugas pada materi ketentuan

\footnotetext{
${ }^{1}$ Rusman, Model-Model pembelajaran. (Jakarta: Rajawali Pres, 2012)

2 Ahmad Ahmadi, Ilmu pendidikan. (Jakarta : Rineka Cipta, 2010)

${ }^{3}$ Hamda Kharisma Putra, Monograf Model Multimedia Interaktif untuk Meningkatkan Pemahaman dan Daya Tarik Pembelajaran. (Jakarta : Penerbit Lakeisha, 2021)
} 
hukum mad 'iwad; (2) Sebagian siswa belum mampu menguasai hukum bacaan mad 'iwad; dan (3) Siswa kurang mampu menjawab pertanyaan guru

Dengan beberapa gejala diatas, maka muncullah masalah yang menjadi penghambat dalam peningkatan daya serap belajar siswa. Hal ini terjadi karena pada saat pembelajaran berlangsung, guru menggunakan metode yang kurang tepat. Selama ini, guru cenderung mengajar dengan metode ceramah, penugasan dan Tanya jawab. Dengan metode yang selama ini dipakai, siswa cenderung bersikap pasif dalam pembelajaran, karena siswa hanya mendengarkan apa yang disampaikan oleh guru meskipun telah diberikan kesempatan oleh guru untuk bertanya mengenai hal-hal yang belum dikuasainya. Kurangnya keaktifan siswa ini akan berdampak pada daya serap belajar siswa. Siswa akan mudah lupa mengenai hal-hal yang dipelajarinya karena siswa jarang bertukar pendapat dengan guru apalagi dengan teman sekelasnya. Keadaan inilah yang menyebabkan rendahnya daya serap belajar siswa pada materi ketentuan hukum bacaan mad 'iwad. Oleh sebab itu, peneliti mencoba menerapkan metode diskusi dalam penyampaian materi pelajaran, karena dengan menggunakan metode diskusi siswa saling bertukar pendapat secara konstruktif sehingga diperoleh keputusan yang lebih baik disamping membiasakan anak didik untuk mendengarkan pendapat orang lain sekalipun berbeda pendapatnya sendiri dan membiasakan bersikap toleran.

Mencermati kelebihan metode diskusi di atas, penulis tertarik ingin melakukan suatu penelitian tindakan kelas dengan judul: “ upaya meningkatkan daya serap belajar siswa pada kompetensi memahami ketentuan hukum bacaan mad 'iwad melalui metode diskusi di kelas VIII B MTs NW Karang Baru tahun pelajaran 2021-2022".

\section{Metode}

Penelitian ini merupakan Penelitian Tindakan Kelas (PTK) dengan model yang dikemukakan Kemmis \& Mc.Taggart. Adapun model PTK dimaksud menggambarkan ada 4 langkah (dan pengulangannya), yang disajikan dalam bagan berikut4:

\footnotetext{
${ }^{4}$ Ekawarna, Penelitian Tindakan Kelas. (Jakarta: referensi, 2013)
} 


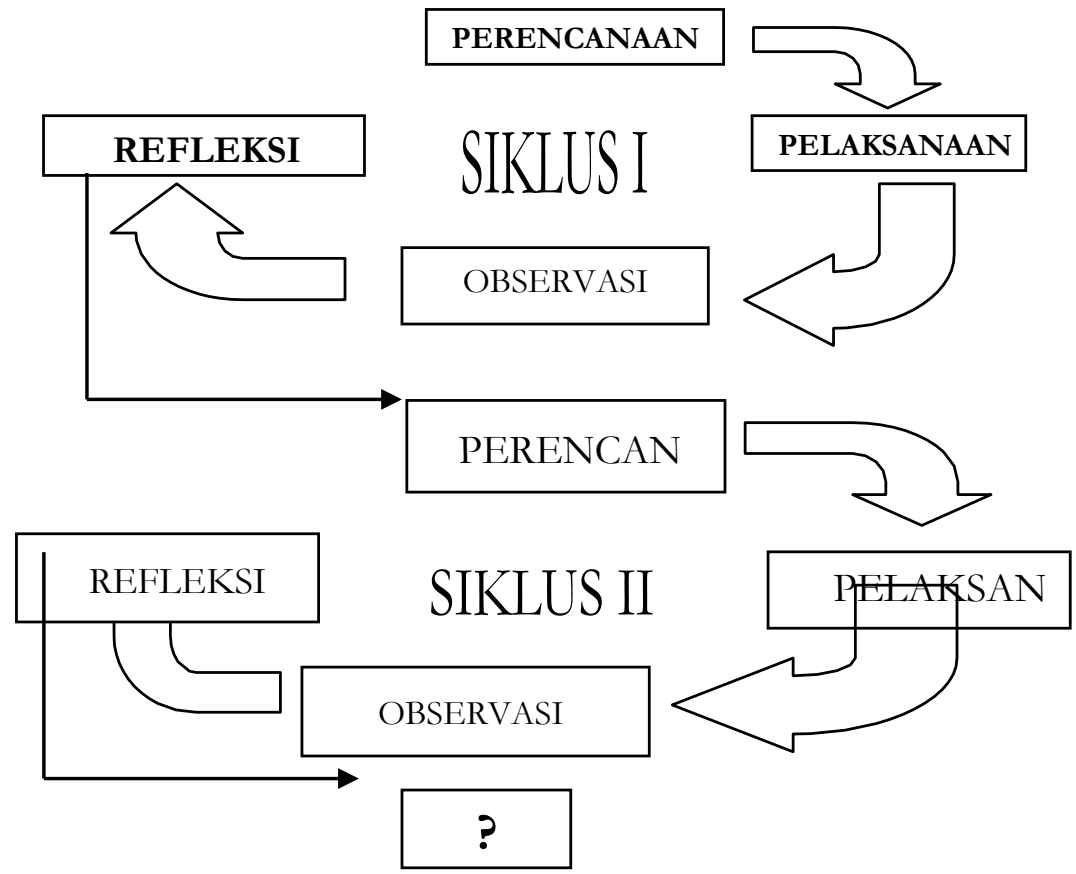

Secara rinci tahapan penelitian ini sebagai berikut5: 1) perencanaan, yaitu menyusun rancangan tindakan : (a) Mengidentifikasi khusus (b) Mengidentifikasi masalah (c) Mencarikan alternative pemecahan (d.) Membuat satuan tindakan. 2) Pelaksanaan tindakan, yaitu implementasi atau penerapanisi rancangan didalam kancah yaitu mengenakan tindaan dikelas. Kegiatan yang dilaksanakan tahap ini adalah melaksanakan tindakan upaya meningkatkan hasil belajar pada mata pelajaran AlQur'an Hadits yang telah direncanakan. 3) Observasi, yaitu pelaksanaan pengamatan oleh pengamatan dalam tahap ini dilaksanakan tindakan dengan menggunakan observasi yangtelah disiapkan. peneliti mempersiapkan lembar observasi yang telah disiapkan untuk mengetahui kondisi kelas terutama daya serap belajar pesertadidik pada mata pelajaran Al-Qur'an Hadits. Dalam penelitian ini hasil pengamatan kemudian diskusikan dengan kolaburator yaitu guru mata pelajaran Al-Qur'an Hadits untuk dicari solusi dari permasalahan yang ada pada waktu pembelajaran berlangsung. 4) refleksi, dilakukan untuk menentukan apakah siklus tersebut harus diulangi atau sudah berhasil 6 .

\footnotetext{
${ }^{5}$ Suharsimi Arikunto. Prosedur Penelitian Suatu Pendekatan Praktik. (Jakarta: Rineka Cipta, 2013)

${ }^{6}$ E. Mulyasa, Praktik Penelitian Tindakan Kelas. (Bandung: PT. Remaja Rosdakarya, 2009)
} 
Adapun dalam rangka pengumpulan data pada penelitian ini, penulis menggunakan metode observasi, tes, dan dokumentasi. Metode Observasi dilakukan terhadap siswa di kelas VIII B MTs NW Karang Baru tahun pelajaran 2021-2022 dengan cara penulis ikut berpartisipasi langsung dalam mengamati kondisi siswa didalam kelas. Tes akhir dilakukan dengan cara tes tertulis untuk mengetahui hasil daya serap peserta didik setelah dilakukan penerapan metode diskusi dalam pembelajaran memahami ketentuan hukum bacaan mad 'iwad pada mata pelajaran Al-Qur'an Hadits. Metode dokumentasi penulis gunakan sebagai pelengkap untuk melengkapi keterangan-keterangan yang penulis butuhkan yaitu memperoleh data-data nilai peserta didik,data tengaga pendidik, data tentang kegiatan belajar mengajar di MTs NW Karang Baru

Data yang sudah dikumpulkan diolah dan dianalisis menggunakan analisis deskriptif (statistic deskriptif) untuk melihat daya serap siswa pada setiap siklus. Ketuntasan individu tercapaiapabila siswa mencapai $77 \%$ dari hasil tesatau nilai 77. Ketuntasan individudihitung dengan rumus:

$$
\text { Nilai Akhir }=\frac{\text { Skor Mental }}{\text { Skor Ideal }} \times 100 \%
$$

(Wahyudin, 2007)

NS $\geq$ KKM maka kategori tuntas,

NS < KKM maka kategori tidak tuntas

NS = Nilai Siswa

Ketuntasan klasikal tercapai apabila 75\% dari seluruh siswa memperoleh dengan nilai minimal 77 maka kelas itudikatakan tuntas. Adapun rumus yangdipergunakan untuk menentukanketuntasan klasikal sebagai berikut:

$$
\begin{array}{cl}
\text { KK }=\frac{J T}{J S} & \times 100 \% \\
\text { KK } & =\text { Ketuntasan klasikal } \\
\text { JT } & =\text { Jumlah siswa yang tuntas } \\
\text { JS } & =\text { Jumlah siswa seluruhnya }
\end{array}
$$


Tingkat kesempurnaan guru dalam menggunakan model pembelajaran diskusi ditentukan dengan 5 klasifikasi dan dihitung dengan cara: (1) Menentukan jumlah klasifikasi yang diinginkan, yaitu 5 klasifikasi yaitu sangat sempurna, sempurna, cukup sempurna, kurang sempurna, dan tidak sempurna. Menentukan interval (I), yaitu : I =

$$
\frac{\text { Skor } \max -\text { Skor } \min }{5}=1=\frac{40-8}{5}=6,4=6
$$

Menentukan table klasifikasi standar penerapan model pembelajaran diskusi, yaitu: (a) Sangat sempurna apabila 33 - 40; (b) Sempurna apabila 25 - 32; (c)Cukup sempurna apabila 17 - 24; (d) Kurang sempurna apabila 9 - 16; dan Tidak sempurna apabila 1 - 8. Dalam penemuan ini penulis akan menggunakan teknik analisis data dengancara mengkategorikan hasil belajar serta mempresentasikan keberhasilan dan batas ketuntasan.

\section{Pembahasan}

Hasil analisis untuk masing setiap siklus menunjukan tren yang positif, yaitu terdapat perkembangan pada setiap siklus yang dilakukan

\section{Siklus I}

Hasil analis data pada siklus 1 disajikan pada tabel 1 berikut:

Tabel 1. Ketuntasan siswa pada siklus 1

\begin{tabular}{lcc}
\hline \multirow{2}{*}{ Ketuntasan } & \multicolumn{2}{c}{ Persentase } \\
& Pretes & Post tes \\
\hline Tuntas & $44,5 \%$ & $77,3 \%$ \\
Belum tuntas & $55,45 \%$ & $22,7 \%$ \\
\hline
\end{tabular}

Berdasarkan data dari hasil post test pada siklus I, terdapat siswa yang mencapai ketuntasan terdapat 17 siswa dengan presentase $77,3 \%$, sedangakan siswa hasil belajarnya belum tuntas mencapai 5 siswa dengan presentase $22,7 \%$, sedangkan hasil pretes siswa, terdapat siswa yang mencapai ketuntasan terdapat 10 siswa dengan presentase 44,45\%, sedangkan siswa yang tidak tuntas mencapai 12 siswa dengan prentase $54,54 \%$, dengan demikian, penerapan diskusi pada siklus I hasil belajar siswa terdapat peningkatan dari sebelum pelaksanaan, yaitu: siswa yang 
mencapai ketuntasan pada hasil pretes mencapai 44,45\%, dan ketuntasan pada hasil postest siklus I mencapai $77,2 \%$ terhadap peningkatan 32,85\%, sedangakan siswa yang belum mencapai ketuntasan menurun 31,84\%. dengan demikian, dilihat dari nilai postest setelah mengikuti pembelajaran dengan penerapan metode diskusi menunjukan bahwa siklus I sudah mengalami peningkatan dari pembelajaran sebelum menggunakan dengan penerapan metode diskusi, namun masih banyak siswa yang belum mengauasai materi pembelajaran dan hasil belajarnya masih di bawah KKM yang ditentukan.

Pada siklus I, guru masuk kelas lalu mengucapkan salam dan mengabsensi kehadiran siswa, guru memberikan apersepsi, guru memberi tahu kepada siswa VIII B mengenai adanya kolaborasi guru dengan siswa untuk mengadakan diskusi tentang ketentuan hukum bacaan Mad 'Iwad. Kemudian guru menuliskan tujuan pembelajaran, setelah itu membentuk kelompok menjadi 3 kelompok, setelah itu guru memberikan buku kepada masing-masing kelompok untuk membaca materi tentang ketentuan hukum bacaan mad 'iwad. Lalu guru memerintahkan perwakilan setiap kelompok mempresentasikan hasil diskusi di depan kelas dan kelompok lain diperbolehkan memberikan pendapat atau saran terkait tentang materi yang disampaikan.

Berdasarkan data dari hasil post test pada siklus I, terdapat siswa yang mencapai ketuntasan terdapat 17 siswa dengan presentase $77,3 \%$, sedangakan siswa hasil belajarnya belum tuntas mencapai 5 siswa dengan presentase $22,7 \%$, sedangkan hasil pre test siswa, terdapat siswa yang mencapai ketuntasan terdapat 10siswa dengan presentase $44,45 \%$, sedangkan siswa yang tidak tuntas mencapai 12 siswa dengan prentase $54,54 \%$, dengan demikian, penerapan metode diskusi pada siklus I hasil belajar siswa terdapat peningkatan dari sebelum pelaksanaan, yaitu: siswa yang mencapai ketuntasan pada hasil pretes mencapai 44,45\%, dan ketuntasan pada hasil postest siklus I mencapai 77,3\% terhadap peningkatan 32,85\%, sedangkan siswa yang belum mencapai ketuntasan menurun 32,84\%. dengan demikian, dilihat dari nilai postest setelah mengikuti pembelajaran dengan penerapan metode diskusi menunjukkan bahwa siklus I sudah mengalami peningkatan dari pembelajaran 
sebelum menggunakan dengan penerapan metode diskusi, namun masih banyak siswa yang belum mengauasai materi pembelajaran dan hasil belajarnya masih di bawah KKM yang ditentukan.

Berdasarkan data yang diperoleh maka tampak tingkat ketuntasan siswa masih rendah hanya mencapai $77,3 \%$ atau 17 siswa yang tuntas dengan rata-rata pencapaian target ketuntasan maka peneliti dan kolaborator beranggapan bahwa hasil ketuntasan siswa maka perlu dilanjutkan penelitian pada siklus ke II, peneliti dan kolaborator pada siklus ke II merubah sistemnya namun tetap menggunakan metode diskusi

\section{Siklus II}

Hasil analis data pada siklus 1 disajikan pada tabel 1 berikut: Tabel 1. Ketuntasan siswa pada siklus 1

\begin{tabular}{lcc}
\hline \multirow{2}{*}{ Ketuntasan } & \multicolumn{2}{c}{ Persentase } \\
& Pretest (Siklus I) & Post tes (Siklus II) \\
\hline Tuntas & $77,3 \%$ & $95,5 \%$ \\
Belum tuntas & $22,7 \%$ & $4,54 \%$ \\
\hline
\end{tabular}

Berdasarkan data dari hasil pre test pada siklus I, terdapat peserta didikyang mencapai ketuntasan terdapat 17 siswa dengan presentase $77,3 \%$, sedangkan peserta didik yang hasil belajarnya belum tuntas mencapai 5 siswa dengan presentase $22,7 \%$, sedangkan hasil post test peserta didik mencapai ketuntasan terdapat 21 siswa dengan presentase 95,45\%, Sedangkan peserta didikyang belum tuntas mencapai 1 siswa. dengan presentase 4,54\% dengan demikian, penerapan model pembelajaran metode diskusi pada siklus II hasil belajar siswa terdapat peningkatan sebelum pelaksanaan, yaitu siswa mencapai ketuntasan dari hasil pretest mencapai 77,7\%, dan ketuntasan dari hasil post test siklus II mencapai 95,45\% terdapat peningkatan $18,15 \%$, sedangkan siswa yang belum mencapai ketuntasan pada hasil pre test $22,7 \%$, dan siswa yang belum mencpai ketuntasan pada hasil post test siklus II mencapai $4,54 \%$ terdapat siswayang belum mencapai ketuntasan menurun sebesar $18,16 \%$. hal ini menunjukkan bahwa hasil belajar dengan menggunakan metode diskusi pada siklus II sudah mengalami peningkatan dari hasil siklus I, meskipun masih terdapat 
beberapa siswa yang belum menguasai materi pembelajaran sebelumnya dan hasilnya masih dibawah KKM yang telah ditentukan.

Pada siklus II, guru masuk kelas lalu mengucapkan salam dan mengabsensi kehadiran siswa , guru memberikan apersepsi, guru memberi tahu kepada siswa VIII B mengenai adanya kolaborasi guru dengan siswa untuk mengadakan diskusi tentang ketentuan hukum bacaan Mad 'Iwad Setelah itu guru melakukan apersepsi dengan menanyakan kembali apa itu mad 'iwad, kemudian menjelaskan tentang Kompetensi dasar, Target tata cara membaca mad 'iwad dengan baik dan benar sesuai dengan ilmu tajwid. Setalah itu mereka membaca kembali materi tentang hukumbacaan mad 'iwad, kemudian guru membagi siswa menjadi 3 kelompok dan mempersilahkan perwakilan masing-masing kelompok maju untuk mempersentasekan hukum bacaan mad 'iawad dengan baik dan benar sesuai dengan kaidah ilmu tajwid. Kemudian guru dan kolaborator memantau dan melakukan pencatatan terhadap proses $\mathrm{KBM}$, kolaborator siap dengan dokumennya untuk melakukan pencatatan. pada siklus II hasil belajar siswa terdapat peningkatan sebelum pelaksanaan, yaitu siswa mencapai ketuntasan dari hasil pretest mencapai $77,7 \%$, dan ketuntasan dari hasil post test siklus II mencapai 95,45\% terdapat peningkatan $18,15 \%$, sedangkan siswa yang belum mencapai ketuntasan pada hasil pre test $22,7 \%$, dan siswa yang belum mencpai ketuntasan pada hasil post test siklus II mencapai 4,54 \% terdapat siswa yang belum mencapai ketuntasan menurun sebesar $18,16 \%$. hal ini menunjukkan bahwa hasil belajar dengan menggunakan metode diskusi pada siklus II sudah mengalami peningkatan dari hasil siklus I, meskipun masih terdapat beberapa siswa yang belum menguasai materi pembelajaran sebelumnya dan hasilnya masih dibawah KKM yang telah ditentukan.

\section{kesimpulan}

1. Kesimpulan

Berdasarkan pembahasan dan hasil analisis data membuktikan bahwa penerapan metode diskusi pada materi ketentuan mad "iwad pada kelas VIII B dapat disimpulkan bahwa dengan melalui penerapan metode diskusi pada materi ketentuan mad "iwad pada kelas VIII B dapat meningkatkan hasil belajar pesetra didik. Hasil belajar peserta 
didik dari siklus I dari nilai rata-rata post test hasil belajar peserta didik yang mencapai ketuntasan baru 77,3 \% sedangkan hasil belajar peserta didik yang tidak tuntas mencapai $22,7 \%$ dan pada siklus II hasil belajar peserta didik yang mencapai ketuntasan 95,45\% sedangkan hasil belajar peserta didik yang belum tuntas 4,54\% peneliti sudah melihat adanya peningkatan pada siklus II dalam proses pembelajaran dengan menggunakan metode dikusi.

2. Saran

a. Bagi Guru

1. Dalam melaksanakan pembelajaran sebaiknya menggunakan model pembelajaran atau metode pembelajaran yang bervariasi sehingga dapat meningkatkan hasil belajar siswa.

2. Menggunakan pembelajaran dalam berkelompok dapat memberi kesempatan lebih besar kepada siswa agar mereka menungkan pendapatnya sehingga peserta didik dapat ikut berperan aktif dalam suatu proses pembelajaran.

3. Guru dapat menerapkan metod diskusi agar dapat tercipta suasana belajar yang menyenangkan, tidak membuat siswa yang tegang, dan cepat jauh dalam mengikuti suatu proses pembelajaran

b. Bagi siswa

1. Siswa perlu meningkatkan motivasi belajarnya terutama dalam ulet menghadapi kesulitan, bekerja kelompok, mencari dan memecahkan masalah pada soal-soal, melaksanakan tugas- tugas yang dibrikan guru.

2. Jika ada pertanyaan yang diberikan guru siswa hendaknya melakukan diskusi dan tukar pendapat atau informasi kepada teman sekelompoknya agar menghasilkan suatu jawaban yang benar dari pertanyaan tersebut.

\section{Daftar Refrensi}

Ahmad Ahmadi, Ilmu pendidikan. (Jakarta : Rineka Cipta, 2010)

E. Mulyasa, Praktik Penelitian Tindakan Kelas. (Bandung : PT. Remaja Rosdakarya, 2009)

Ekawarna, Penelitian Tindakan Kelas. (Jakarta: referensi, 2013) 
Hamda Kharisma Putra, Monograf Model Multimedia Interaktif untuk Meningkatkan Pemahaman dan Daya Tarik Pembelajaran. (Jakarta : Penerbit Lakeisha, 2021).

Rusman, Model-Model pembelajaran. (Jakarta: Rajawali Pres, 2012)

Suharsimi Arikunto. Prosedur Penelitian Suatu Pendekatan Praktik. Jakarta: Rineka Cipta, 2013 